\title{
Exports Performance of Nepal: What Can Be Done?
}

\author{
Ramesh C. Paudel ${ }^{1}$ \\ ${ }^{1}$ Arndt Corden Department of Economics, Australian National University, Canberra, Australia and Tribhuvan \\ University, Kathmandu, Nepal \\ Correspondence: Ramesh C. Paudel, Tribhuvan University, Central Department of Economics, Kirtipur, Kathmandu, \\ Nepal. E-mail: ramesh.paudel@alumni.anu.edu.au
}

\author{
Received: June 17, $2019 \quad$ Accepted: July 18, $2019 \quad$ Available online: July 26, 2019 \\ doi:10.11114/aef.v6i5.4413 URL: https://doi.org/10.11114/aef.v6i5.4413
}

\begin{abstract}
What can be done to improve the export performance of Nepal? is an important question as the Nepal's progress on export is not satisfactory. Yes, the performance has not met the expectation of the stakeholders and even of the policymakers. In addition to the detailed descriptive analysis, I use a standard gravity modelling technique to answer this question using SITC, 5 digits data for the period 2005-2018. The econometric estimation results suggest that, Nepal could not gain meaningfully from its earlier steps in the liberalization and reform procedures rather its loosing export position. To come out from this situation, the estimated results suggest that Nepal's should focus on some products that have high-value to weight targeting to reduce the transportation costs meaningfully. Nepal should adopt specific strategies, such as, build trade and manufacturing-focused infrastructure, initiate for bilateral trade agreements, improve the quality of the governance side by side of the reform process and second generation reform programs, tie up the education with national production system, and adjust the exchange rate system making more export friendly.
\end{abstract}

JEL Code: F130, F110, O50

Keywords: exports performance, trade models, landlocked countries, high-value to weight products

\section{Background}

Nepal's export performance is stagnant and has not met the expectation of the policy makers and stakeholders despite various efforts in the policy contexts. The manufacturing sector's contribution is recorded below 10 percent for many years. The data suggest that Nepal's share of exports in the global context is declining, not only that, its share in landlocked developing countries' exports also declining (Table 1). This background of Nepal's export performance seeks a systematic analysis of her challenges related with the international trade and prepare the suitable strategies for the betterment of national economy in this globalization era-on which a country without proper export pattern seems almost impossible to progress economically.

All else remain same, as being a landlocked country, Nepal is naturally disadvantaged for international trade. Therefore, unless it makes specific strategies Nepal's trade competitiveness remains low. This paper intends to seek the answers on how Nepal can, at least, compensate these disadvantages nor what can be done int this regard? Is Nepal only landlocked or policy locked, and strategies lacked too? To do so this research paper focuses on the issues of policy, institutional and infrastructure problems those have to be addressed for expanding exports under the 'natural' constraints imposed by Landlockedness. Then, it suggests the specific strategies for the betterment of Nepalese exports in the light that globally, exports from landlocked developing countries (LLDCs) have generally grown at a slower rate compared to other developing countries, even after major trade policy reforms in LLDCs in a faster pace (Limão \& Venables, 2001; World Bank, 2019a).

This study aims to analyse such challenges and examine Nepal's export performance before suggesting the strategies to insure Nepal's performance. This study is built on Ramesh C. Paudel and Burke (2015) and Ramesh C Paudel and Wagle (2017), which, explaining the situation of landlockedness of the country, state that Nepal would be in better position in terms of export if it attempts to identify the high-value to weight products with their comparative advantage.

The literature and trade data also suggest that some landlocked countries have better performance of export compared to their other landlocked counterparts. Nepal's problem is it is going behind even with other landlocked developing countries. This scenario suggests that landlockedness is not destiny, and domestic policy choices and strategies can 
make a huge positive difference (Ramesh C Paudel, 2014). Hence, a study on the opportunities and policy options with suitable strategies for export diversification is relevant to the contemporary export policy discussion in Nepal.

This study econometrically investigates a gravity model using 3 digits product level data of merchandise exports to its largest 15 partners over 11 years spanning 2005-2018. In addition to the attention on high-value to weight, this paper analyses other important issues such as trade reform, education, governance and infrastructure for the betterment of export trade. Here, I understand the limit of country specific studies such as this one but can provide a benchmark policy guiding for other similar countries. This study also makes a comparative analysis of the products selected to export highlighting the potential competitors in the global market and put some recommendation as the export strategies on those products produced in the border regions with some specific case studies.

Our findings suggest adopting a trade policy focusing on high-value to weight products to minimise the transportation costs. Also, the results suggest tying Nepal's education system with the production system improving the quality of the governance that should go ahead side by side with liberalization and reform. These findings may be of interest for other such countries, for example the other landlocked developing countries that face the same geographical constraints. As far as we are aware, this is the attempt to provide a detail and systematic analysis focusing on the high-value weight products to improve the export performance of Nepal.

This paper is structured as follows. I discuss on brief literature in Section 2, then Nepal's trade patterns are discussed in Section 3. Section 4 is devoted for research methodology of the paper, Section 5 is about the results and interpretation, and the final section concludes with some policy recommendations in the Nepal's trade context.

Table 1. Nepal's merchandise exports, 1960-2018

\begin{tabular}{lccc}
\hline Year & Value US\$ (million) & Share of LLDCs (\%) & Share world (\%) \\
\hline 1960 & 17.0 & 1.7 & 0.014 \\
1970 & 42.4 & 1.7 & 0.014 \\
1980 & 80.0 & 1.0 & 0.004 \\
1990 & 204.0 & 1.9 & 0.006 \\
2000 & 804.0 & 5.5 & 0.012 \\
2005 & 863.2 & 2.7 & 0.008 \\
2010 & 855.8 & 1.4 & 0.006 \\
2015 & 720.0 & 1.2 & 0.004 \\
2018 & 840.0 & 1.1 & 0.003 \\
\hline
\end{tabular}

Source: World Bank (2019a)

Note: LLDC = landlocked developing country. LLDCs members are the same throughout the period and exclude post-Soviet countries.

\section{Brief Literature Review}

Nepal is a landlocked country, being so it has some disadvantages for international trade. Behar and Venables (2010) analyse the trade flows considering different aspects of transportation costs including landlockedness and other factors related with economic geography and stands on this fact. Other studies too indicate the negative impact of landlockedness on export performance, for example, Grigoriou (2007), Silva and Tenreyro (2006) and $\mathrm{Ng}$ and Yeats (2003). Faye (2004) suggests landlocked countries stand behind their coastal neighbours in external trade, and this is due to the transportation costs to the coast. Earlier, Limão and Venables (2001) find that the median landlocked country trades 30 percent of the median coastal country; however, in case of export, this figure goes further low.

Hummels (1999), in a research work, says one way to progress in exports of LLDCs is to focus on high-value to weight products suitable for air transport. In this regard, the United States' import by mode of transportation data are motivational for this, which show that the United States used the air transportation for $22 \%$ of import and $29 \%$ of exports of the total value of those respectively in 2011 (Chambers \& Liu, 2012). Overall, the annual average growth of international air cargo (the weight) is recorded about 5\%, compared to that of ocean borne cargo about $3 \%$ over the past decade (United States Department of Transportation, 2010). This changing trend on mode of transport of international trade is good news for landlocked countries. This shows that some countries - particularly the landlocked country like Nepal, have a chance to do lot focusing on high-value to weight products. But Nepal needs to do a lot in the air 
infrastructure to connect domestic market to international market. If it happens, it will connect Nepal to the global production sharing network.

It is because only 17.63 million Kilograms of cargo (imports and exports) were handled by air services in 2009 via 20 international air lines networks in 35 countries. About 17 percent of total exports used air transportation in the same year. Railway transport could be a more efficient way to connect to Kolkata seaport to export to third countries; it would also be a very effective means of transport to connect the wider Indian market via one of the biggest railway networks in the World. Unfortunately, Nepal has a very limited (about 56 kilometres) railway facility to connect with the Indian rail network, and the rail network in Nepal is not reliable. Of the 56 kilometres of railway lines, only 29 kilometres are being used because of managerial inefficiency (Rajkarnikar, 2010). Moreover, the railway network has never been a priority item on the agenda of the policy makers in the country. Therefore, if air transportation is managed properly, it has a wider possibility to match with strategy of cost reduction for the exports. The current government has given specific priority in rail service, the outcome has not been realised yet, and business sector is waiting the well execution of its.

One string of literature discusses on the reason of the backwardness of the LLDCs in terms of international trade and raise the question whether they are so whether due to landlocked or policy locked. For example, Borchert, Gootiiz, Grover, and Mattoo (2012) highlights the importance of the policy reforms followed by the strong monitoring mechanism and concludes the structured policy reform helps reducing the adverse impact of the landlockedness. This motivates us to analyse the policy reforms in Nepal what strategies Nepal needs to adopt in this context.

Since 1980s, mostly, the focus in the literature is found to be related with trade policies; especially, the reduction or abolition of tariffs and non-tariff barriers against protectionism to creating more trade friendly policies.

If we look at the history, Nepal has passed through three distinct phases of trade policy: a free trade regime (1923-1956), a protectionist regime (1956-1986), and towards a relatively open regime from 1986 onwards. This means Nepal is an earlier entrant in the trade policy reform and liberalisation. A point to note is that all these regimes have fundamentally followed the mixed economy concept. Nepal boarded on market-oriented policy reforms in the mid-1980s replacing the inward-oriented policy that failed to fulfil the much needed growth and development objectives (Sharma, 2001). However, a major policy reform and relevant activities occurred in the early 1990s (Acharya, Khatiwada, \& Aryal, 2003). Nepal became the earlier entrant to join the world trade organisation (WTO) negotiation process in April 2004 with expectation to meet the expectation from the business community making more trade friendly environment. Since 2001/02, the liberalisation trend was slightly reversed imposing some import taxes in addition to customs duties and this situation remain unchanged until 2010 (Pursell, 2011) as listed in the Table 2, which also shows the tariff rates are higher than that of India since 2005-2010 period. During 2015-2018, Nepal's tariffs rates are almost double compared to that of India's tariff rates on average.

However, all these stories are unable to fulfil the growth needs and boosting up the exports. Noting the background of the geographical constraints and policy reform story episode, we argue Nepal is landlocked, not a policy locked rather it has lack of the strategies. This argument is based on a note from an old but strategic research work, Helleiner (1973), which with a depth analysis, states that the products with high-value relative to their weight are suitable for the country with greater distance to market or those have higher transportation costs.

Table 2. Tariff Rates: Comparison with India (in \%)

\begin{tabular}{lllc}
\hline Period Average & Nepal & India & Difference \\
\hline $1990-95$ & 15.89 & 40.71 & 24.82 \\
$1995-00$ & 16.62 & 23.98 & 7.36 \\
$2000-05$ & 14.87 & 21.82 & 6.95 \\
$2005-10$ & 12.46 & 8.95 & -3.51 \\
$2010-15$ & 11.93 & 6.50 & -5.43 \\
$2015-18$ & 12.16 & 5.60 & -6.56 \\
\hline
\end{tabular}

Source: World Bank (2019a), Weighted Average Applied Tariff Rates for all products

\section{Trends and Patterns of Nepal Export Trade}

Nepal's export trade has been stagnant and has peculiar pattern. Table 3 shows the top 15 products (SITC revision 3 , five digits' data) exported from Nepal over different years. These items cover almost 60 percent of Nepal's exports in 
2015. I have selected year 2015 because this year has most diverse exports in the recent years despite exogenous shocks, i.e., earthquake and trade blockade from India. A notable lesson from this table is that the products have been changed over the specified time. For example, out of 15 products exported in 2015, only two products were exported from Nepal in 2000. This indicates lot of products have been emerged capturing various market dynamics and some exported commodities have face death. Only two products, such as, product code $07525 \mathrm{Nutmeg} / \mathrm{mace} / \mathrm{cardamoms}$ - spices and product code 84612 Shawl/scarf - type of clothes have survived over the selected period.

The commodity composition of Nepalese exports suggests that Nepal is doing better in the high-value-low-weight products. It is reasonable due to lower amount of transportation costs on these items. The data shows that the price to weight ratio of mostly exported items, such as spices, textile yarn, clothing accessories, iron or steel wire, special yarn, floor coverings, is high. The heavier items such as product code 67413 Zinc coated steel, 67949 Iron/steel piper are losing the ground every year with some exception.

The data also shows that Nepal's product diversification is increasing every year. With only 907 products exported in 2000, the data increased to 1322 in 2015.

Table 3. Nepal's top 15 exporting products, 2000-2015

\begin{tabular}{|c|c|c|c|c|c|c|c|c|c|c|c|}
\hline \multirow[b]{2}{*}{$\begin{array}{l}\text { Product } \\
\text { code }\end{array}$} & \multirow[b]{2}{*}{ Products } & \multicolumn{2}{|c|}{2015} & \multicolumn{2}{|r|}{2014} & \multicolumn{2}{|r|}{2010} & \multicolumn{2}{|c|}{2005} & \multicolumn{2}{|c|}{2000} \\
\hline & & $\begin{array}{c}\text { Ran } \\
k \\
\text { (out } \\
\text { of } \\
1322 \\
\text { ) }\end{array}$ & $\begin{array}{c}\text { Share } \\
\%\end{array}$ & $\begin{array}{c}\text { Ran } \\
k \\
\text { (out } \\
\text { of } \\
1020 \\
\text { ) }\end{array}$ & $\begin{array}{c}\text { Share } \\
\%\end{array}$ & $\begin{array}{c}\text { Ran } \\
k \\
\text { (out } \\
\text { of } \\
959)\end{array}$ & $\begin{array}{c}\text { Share } \\
\%\end{array}$ & $\begin{array}{c}\text { Ran } \\
k \\
\text { (out } \\
\text { of } \\
962 \\
\text { ) }\end{array}$ & $\begin{array}{c}\text { Share } \\
\%\end{array}$ & $\begin{array}{c}\text { Ran } \\
k \\
\text { (out } \\
\text { of } \\
907 \\
\text { ) }\end{array}$ & $\begin{array}{c}\text { Share } \\
\%\end{array}$ \\
\hline 11102 & $\begin{array}{l}\text { Flavored waters } \\
\text { non-alcoholic }\end{array}$ & 1 & 11 & 1 & 11 & 7 & 3 & 5 & 3 & NA & NA \\
\hline 65921 & Carpet,knotted,wool/hair & 2 & 11 & 2 & 10 & 1 & 13 & 1 & 24 & NA & NA \\
\hline 7525 & Nutmeg/mace/cardamoms & 3 & 6 & 10 & 3 & 8 & 3 & 8 & 2 & 13 & 1 \\
\hline 89399 & Othr plastc articles & 4 & 5 & 3 & 6 & 3 & 7 & NA & NA & NA & NA \\
\hline 84612 & Shawl/scarf/etc not kn/c & 5 & 4 & 5 & 4 & 5 & 4 & 3 & 4 & 2 & 16 \\
\hline 65182 & Syn stap $(>85 \%)$ yarn bulk & 6 & 4 & 4 & 5 & 4 & 5 & 4 & 3 & NA & NA \\
\hline 65184 & Syn $\operatorname{stap}(<85 \%)$ yarn bulk & 7 & 4 & 9 & 3 & NA & NA & NA & NA & NA & NA \\
\hline 85151 & $\begin{array}{l}\text { Footwears texttiles up,ru/pl } \\
\text { sole }\end{array}$ & 8 & 3 & 7 & 3 & NA & NA & NA & NA & NA & NA \\
\hline 65929 & Carpet,knotted,oth text & 9 & 2 & 12 & 2 & NA & NA & NA & NA & NA & NA \\
\hline 65811 & Jute etc sacks/bags & 10 & 2 & 13 & 2 & 6 & 4 & NA & NA & NA & NA \\
\hline 5779 & Nuts edible,fresh/dry & 11 & 2 & 8 & 3 & 11 & 2 & NA & NA & $\mathrm{Na}$ & NA \\
\hline 7414 & Black tea, bulk & 12 & 2 & NA & NA & 10 & 2 & NA & NA & NA & NA \\
\hline 59814 & Rosin/resin acid/oil & 13 & 2 & NA & NA & 15 & 1 & NA & NA & NA & NA \\
\hline 67413 & Zinc coated steel $w>600$ & 14 & 2 & 6 & 3 & 2 & 10 & 7 & 2 & NA & NA \\
\hline 67949 & Iron/steel pipes/etc & 15 & 1 & 14 & 2 & NA & NA & NA & NA & NA & NA \\
\hline
\end{tabular}

Source: Author's calculation from World Bank (2019b)

Note: NA refers not in top 15 , mirror data are used

If we look about the top exporting destination countries of Nepalese exports, India remains the leading destination throughout the period while Australia and Singapore have emerged within top 15 destination of Nepal's exports. Table 4 presents the top 15 destinations of Nepalese exports for five different years, 2000, 2005 and 2010, 2014 and 2015 to analyse how the destinations of the exports have changed over the specified period. The USA and the European Union (EU) remain in second and third position in different years. India's share remains consistently over 50 percent after 2010. Germany's share is declining over the period but able to secure top 5 position consistently. It is due to the exports to the OECD countries were mainly garments and textiles, which have declined substantially since 2001 due to various reasons.

Exports to United Kingdom (UK) and France seem to fluctuate without losing its position. Bhutan, Australia, and Netherlands were new countries in the top 15 in 2010, while Portugal, Belgium, and Spain exited from the top 15 destinations in 2010. China's position has gradually risen, and Japan's position declined gradually in 2010 compared to 2000.

The number of destination countries of Nepal's exports have increased substantially, 118 from 96, since 2000 to 2015. 
This number reached to 120 in 2010 among the selected years. This scenario shows an increasing diversification of the destinations.

Table 4. Nepal's exports destination profile of top 15 countries, 2000-2015

\begin{tabular}{|c|c|c|c|c|c|c|c|c|c|c|}
\hline \multirow[b]{2}{*}{ Country } & \multicolumn{2}{|l|}{2015} & \multicolumn{2}{|l|}{2014} & \multicolumn{2}{|l|}{2010} & \multicolumn{2}{|l|}{2005} & \multicolumn{2}{|c|}{2000} \\
\hline & $\begin{array}{c}\text { Rank (out of } \\
118)\end{array}$ & $\begin{array}{c}\text { Share } \\
\%\end{array}$ & $\begin{array}{c}\text { Rank (out of } \\
117)\end{array}$ & $\begin{array}{c}\text { Share } \\
\%\end{array}$ & $\begin{array}{c}\text { Rank (out of } \\
120 \text { ) }\end{array}$ & $\begin{array}{c}\text { Share } \\
\%\end{array}$ & $\begin{array}{c}\text { Rank (out of } \\
\text { 111) }\end{array}$ & $\begin{array}{c}\text { Share } \\
\%\end{array}$ & $\begin{array}{l}\text { Rank (out } \\
\text { of 96) }\end{array}$ & $\begin{array}{c}\text { Share } \\
\%\end{array}$ \\
\hline India & 1 & 53.3 & 1 & 54.3 & 1 & 56.2 & 1 & 48.1 & 1 & 27.72 \\
\hline $\begin{array}{l}\text { EuropeanU } \\
\text { nion* }\end{array}$ & 2 & 11.9 & 2 & 11.3 & 2 & 12.5 & 3 & 14.5 & 3 & 17.84 \\
\hline $\begin{array}{l}\text { United } \\
\text { States } \\
\text { Germany }\end{array}$ & $\begin{array}{l}3 \\
4\end{array}$ & $\begin{array}{c}10.1 \\
40\end{array}$ & $\begin{array}{l}3 \\
5\end{array}$ & $\begin{array}{l}8.9 \\
37\end{array}$ & $\begin{array}{l}3 \\
4\end{array}$ & $\begin{array}{l}7.4 \\
4.7\end{array}$ & $\begin{array}{l}2 \\
4\end{array}$ & 15.1 & $\begin{array}{l}2 \\
4\end{array}$ & $\begin{array}{c}27.16 \\
103\end{array}$ \\
\hline $\begin{array}{l}\text { Germany } \\
\text { United }\end{array}$ & 4 & 4.0 & 5 & 3.7 & 4 & 4.7 & 4 & 6.2 & 4 & 10.3 \\
\hline Kingdom & 5 & 3.0 & 6 & 2.4 & 5 & 2.3 & 5 & 2.3 & 6 & 2.1 \\
\hline China & 6 & 2.5 & 4 & 4.6 & 9 & 1.3 & 10 & 1.1 & 13 & 0.8 \\
\hline France & 7 & 1.8 & 7 & 1.9 & 6 & 2.3 & 6 & 1.7 & 7 & 1.8 \\
\hline Japan & 8 & 1.7 & 9 & 1.5 & 12 & 1 & 9 & 1.3 & 5 & 3.1 \\
\hline Turkey & 9 & 1.7 & 8 & 1.7 & 11 & 1 & 15 & 0.5 & NA & NA \\
\hline Canada & 10 & 1.2 & 11 & 1.1 & 7 & 1.7 & 8 & 1.3 & 12 & 0.8 \\
\hline Italy & 11 & 1.2 & 10 & 1.2 & 10 & 1.2 & 7 & 1.4 & 9 & 1.1 \\
\hline Switzerland & 12 & 1.1 & 12 & 0.9 & 14 & 0.6 & 14 & 0.6 & 8 & 1.4 \\
\hline Australia & 13 & 0.6 & 14 & 0.6 & 13 & 0.8 & NA & NA & NA & NA \\
\hline Singapore & 14 & 0.6 & 15 & 0.4 & NA & NA & NA & NA & NA & NA \\
\hline Netherlands & 15 & 0.5 & 12 & 0.7 & 15 & 0.5 & NA & NA & 14 & 0.6 \\
\hline
\end{tabular}

Source: Author's calculation from World Bank (2019b)

Note: NA refers not in top 15 countries, mirror data are used. *If we take European Union as region, then $15^{\text {th }}$ country would be Hongkong as used in econometric analysis.

Nepal's position in top 15 exported products in the global market is very poor compare to those of its competitors in the global context. Table 5 documents Nepal's top products exported in 2015 and Nepal's position in the global market listing top 10 exporters of Nepal's favourite 15 products. It shows that the flavoured waters non-alcoholic has the first ranked product among the 1322 products exported from Nepal and it has a share of $11 \%$ in total Nepal's export. Notably, this product is exported by 140 countries in the world and Nepal's position there remains in $136^{\text {th }}$. This indicates Nepal is not performing even in the average level for this product.

Nepal's position in the global export for three products ranked in top five, such as, for carpet, knotted wool/hair and Nutmeg/mace/cardamoms both products have $4^{\text {th }}$ position, while another one, Jute etc. sacks/bags, has been in third position. Other than that Nepal's position does not remain within top 10. China, United States, European Union and emerging economies are the key exporter of Nepal's top 15 products too. 
Table 5. Top 10 exporters of Nepal's top 15 exported products and Nepal's position 2015

\begin{tabular}{|c|c|c|}
\hline $\begin{array}{l}\text { Product } \\
\text { code (rank } \\
\text { in Nepal) }\end{array}$ & Products & Top 10 exporter countries (Nepal's position, out of total exporters) \\
\hline 1110 & $\begin{array}{l}\text { Flavoured waters } \\
\text { non-alcoholic }\end{array}$ & $\begin{array}{l}\text { European Union, Switzerland, Austria, Germany, Netherlands, United } \\
\text { States, Thailand, Belgium, France and United Kingdom (136 out of } 140 \\
\text { countries) }\end{array}$ \\
\hline 6592 & $\begin{array}{l}\text { Carpet, knotted, } \\
\text { wool/hair }\end{array}$ & $\begin{array}{l}\text { India, Pakistan, Afghanistan, Nepal, Turkey, China, Germany, European } \\
\text { Union, Italy and Denmark ( } 4 \text { out of } 89 \text { countries) }\end{array}$ \\
\hline 0752 & $\begin{array}{l}\text { itmeg/mace/carda } \\
\text { ms }\end{array}$ & $\begin{array}{l}\text { Guatemala, India, Indonesia, Nepal, Netherlands, Singapore, Sri Lanka, } \\
\text { Vietnam, Germany and European Union ( } 4 \text { out of } 90 \text { countries) }\end{array}$ \\
\hline 8939 & $\begin{array}{l}\text { Other } \\
\text { articles }\end{array}$ & $\begin{array}{l}\text { China, Germany, European Union, United States, Italy, France, } \\
\text { Netherlands, Japan, Mexico and United Kingdom (94 out of } 142 \\
\text { countries) }\end{array}$ \\
\hline 8461 & Shawl/s & $\begin{array}{l}\text { China, India, European Union, Italy, France, Germany, United } \\
\text { Kingdom, Spain, Turkey and Denmark (16 out of } 120 \text { countries) }\end{array}$ \\
\hline $65182(6)$ & $\begin{array}{l}\text { Synthetic } \\
\text { stap }(>85 \%) \text { yarn } \\
\text { bulk }\end{array}$ & $\begin{array}{l}\text { China, Indonesia, Turkey, India, Germany, Italy, Slovak Republic, } \\
\text { United States, Romania and European Union ( } 15 \text { out of } 88 \text { countries) }\end{array}$ \\
\hline 6518 & $\begin{array}{l}\text { Synthetic stap } \\
(<85 \%) \text { yarn bulk }\end{array}$ & $\begin{array}{l}\text { China, United States, India, Indonesia, Vietnam, Italy, European Union, } \\
\text { Thailand, Turkey and Germany ( } 15 \text { out of } 87 \text { countries) }\end{array}$ \\
\hline & & $\begin{array}{l}\text { China, Vietnam, Italy, Indonesia, European Union, Belgium, Germany, } \\
\text { Netherlands, Spain and Czech Republic ( } 39 \text { out of } 123 \text { countries) }\end{array}$ \\
\hline 851 & $\begin{array}{l}\text { otwears, textiles, } \\
\text { le }\end{array}$ & \\
\hline 6592 & $\begin{array}{l}\text { Carpet, knotted, } \\
\text { cloth textile }\end{array}$ & $\begin{array}{l}\text { Egypt, Arab Rep., India, China, European Union, Turkey, Germany, } \\
\text { United States, Italy, United Kingdom and France ( } 55 \text { out of } 105 \\
\text { countries) }\end{array}$ \\
\hline 65811 & Jute etc. sacks/bags & $\begin{array}{l}\text { Bangladesh, India, Nepal, European Union, United Kingdom, Thailand, } \\
\text { China, Cambodia, Belgium and Pakistan ( } 3 \text { out of } 112 \text { countries) }\end{array}$ \\
\hline $05779(11)$ & $\begin{array}{l}\text { Nuts } \\
\text { fresh/dry }\end{array}$ & $\begin{array}{l}\text { United States, Indonesia, South Africa, China, Australia, Germany, Sri } \\
\text { Lanka, Netherlands, Turkey and Singapore (19 out of } 120 \text { countries) }\end{array}$ \\
\hline $07414(12)$ & Black tea, bulk & $\begin{array}{l}\text { Sri Lanka, India, China, Argentina, Vietnam, Indonesia, Germany, } \\
\text { Malawi, Uganda and Tanzania (17 out of } 114 \text { countries) }\end{array}$ \\
\hline $59814(13)$ & Rosin/resin acid/oil & $\begin{array}{l}\text { China, Portugal, United States, Belgium, Indonesia, Brazil, Netherlands, } \\
\text { European Union, Finland and Sweden ( } 21 \text { out of } 77 \text { countries) }\end{array}$ \\
\hline $67413(14)$ & $\begin{array}{l}\text { Zinc coated steel } \\
w>600\end{array}$ & $\begin{array}{l}\text { China, Korea, Rep., Belgium, Netherlands, Japan, Italy, Germany, } \\
\text { European Union, India and France ( } 43 \text { out of } 111 \text { countries) }\end{array}$ \\
\hline $67949(15)$ & Iron/steel pipes etc. & $\begin{array}{l}\text { European Union, China, Oman, India, Pakistan, United States, Italy, } \\
\text { Korea, Rep., Singapore and United Kingdom ( } 37 \text { out of } 131 \text { countries) }\end{array}$ \\
\hline
\end{tabular}

Source: Author's calculation from World Bank (2019b) 


\section{Research Methodology}

Tinbergen (1962) proposed the original gravity model, which is known as a "work horse" among international trade economists (Bergeijk \& Brakman, 2010). This model explains trade flows in terms of GDP of reporting and partner countries and geographic distance between countries. I examine the model as listed in equation (1) applying the gravity model approach to examine the trade determinants of Nepal so that a credible policy recommendation possible on what can be done to improve the export performance of Nepal. This model is fitted in the gravity model framework and has been augmented based on the literature:

$$
\begin{gathered}
\operatorname{Ln}\left(X_{p, i j, t}\right)=\alpha+\beta_{1}\left(L I B_{i, t}\right)+\beta_{2}\left(E D U_{i, t}\right)+\beta_{3} \operatorname{Ln}\left(V A L W T_{i, t}\right)+\beta_{4}\left(L P I_{i, t}\right)+\beta_{5} \operatorname{Ln}\left(G D P_{i, t} x G D P_{j, t}\right)+\beta_{6} \operatorname{Ln}\left(D i s_{i j}\right) \\
+\beta_{7}\left(L A N_{i j, t}\right)+\beta_{8} \operatorname{Ln}\left(B O R_{i j, t}\right)+\beta_{9}\left(B T A_{i j, t}\right)+\varepsilon_{i j, t}
\end{gathered}
$$

where,

$L n$ denotes to the natural logarithm, subscripts $p, i$ and $j$ refer to the product, exporter and the partner country in bilateral trade respectively, and $t$ refers to the time - year.

The variables are listed in Appendix 1 with their details, data sources and the postulated sign of the regression coefficient for the explanatory variables in brackets.

The last term of the equation (1) is the error term. The error component structure is presented in equation (2):

$$
\varepsilon_{i j, t}=\mu_{i j, t}+\theta_{t}+\varphi_{i j, t}
$$

Where,

$\mu_{i j, t}$ is a fixed effect that might be correlated with explanatory variables, $\theta_{t}$ captures the time-specific effects common to all cross-section units, and $\varphi_{i j, t}$ is an error term uncorrelated across cross-section units and over time periods.

The dependent variable is at product level, exports (X) from Nepal to its top 15 partners, measured in US\$ in the log form, as recorded in SITC revision 3 at 5-digit data level. Nepal's exports to these 15 countries cover above 95 percent of total exports. Among the explanatory variables, GDP of the trading partners has been measured in US\$ and product of them are used as a variable, distance (DIS) is measured in kilometres for the distance between the most populated cities (business capitals) of partner countries. The variable GDP of exporting and partner countries has been widely explained in the literature and does not need further explanation.

Trade reform (LIB) is measured by the weighted average tariff rate as it helps to compare the level of openness of a country in terms of international trade. Language (LAN) is also a binary dummy variable, that is, 1 if trading countries have a common official language and 0 otherwise. In our sample, there is no common official language among trading partners of Nepal, so dropped. Similarly, border (BOR) is a binary dummy variable representing whether the trading countries share a common border. It is proxied by the weighted average tariff rate for all products, and a negative sign is expected, meaning that the lower the tariff rate, the higher the export performance.

The variables: liberalization (LIB), high-value to weight products (LVALWT) and education (EDU) are of major interest of this study. LVALWT is measured by the price to weight ratio of the products. EDU is measured in three ways, first, by the gross enrolment in primary level education, second by the gross enrolment in the secondary level education, and third by the gross enrolment in the tertiary education. BTA refers to the bilateral trade agreements as a dummy variable. The value of this variable is 1 if Nepal has BTA with trading partners. In this case, among the Nepal's selected partners, Nepal does not have such agreements implemented fully, so dropped.

The model is estimated using a panel data set of bilateral export trade over the period 2005-2018. The data for exports, GDP in US\$ and weighted average tariff rate are collected from World Bank (2019a) and are linearly interpolated to fill in the gaps for some years. The distance, language and border data were compiled from CEPII (2016). The data for bilateral trade agreements (BTA) were collected from De Sousa (2012); these are based on the bilateral trade agreements reported to the WTO by the relevant countries. Other data are from the different database of the World Bank and are cited accordingly.

First, the model is estimated using the advance econometric technique - Poisson pseudo maximum likelihood (PPML) estimator, which best fits to exports data gap and the fluctuation of trade volume substantially. Our data have such gap as the estimation uses at the product level's data.

Then, for the robustness check, we introduce a new variable governance and the data for which are collected from World Bank (2019c). This variable is constructed taking the average of control of corruption and rule of law scores as discussed in Kaufmann, Kraay, and Mastruzzi (2011).

Overall, the analysis shows that the supply side constraints, rather than the demand-market side factor, are important to boost the export performance of Nepal. 


\section{The Results}

The econometric estimation conducted in this chapter suggests some important findings on Nepal's exports. Result Table 6 and 7 combinedly present the results for the gravity estimation using the advance econometric techniquePoisson pseudo maximum likelihood (PPML) estimator, indicating that a $1 \%$ increase in the focus on high-value to weight products is associated with an increasing Nepal's exports to that partner of more than $0.20 \%$, on average. This confirms that Nepal will gain more on trade if focus is given on such products in the national level. For the given period, 2005-2018, liberalization does not have such significant impact in the exports, as not much have been done to improve the liberalization and reform situation of the trade, despite being the earlier entrant in the reform regime. Even, the coefficients are too small, statistically significant with opposite expected sign indicating that Nepal has been unable to grab the opportunity from liberalization to enhance the trade performance. The more openness has impacted export the more in the negative way.

The logistic performance index, product of partners' GDP, distance have the expected sign of the coefficients as in other literature. The impact of education variables seems not to be such influential for export performance. This situation of education correctly reflects the scenario of the trade and education relationship which is not perfectly designed to boost the trade performance.

Table 6. Gravity model PPML estimation results, 2005-2018

\begin{tabular}{|c|c|c|c|c|c|}
\hline Dependent variable: exports US\$ & (PPML-FE) & (PPML-FE) & (PPML-FE) & (PPML-FE) & (PPML-RE) \\
\hline High-value to weight products-log & $\begin{array}{r}0.197 * * * \\
(0.054)\end{array}$ & $\begin{array}{r}0.197 * * * \\
(0.055)\end{array}$ & $\begin{array}{r}0.200 * * * \\
(0.055)\end{array}$ & $\begin{array}{r}0.199 * * * \\
(0.055)\end{array}$ & $\begin{array}{r}0.199 * * * * \\
(0.055)\end{array}$ \\
\hline Liberalization & $\begin{array}{l}0.001^{*} \\
(0.000)\end{array}$ & $\begin{array}{r}0.001 * * * \\
(0.000)\end{array}$ & $\begin{array}{r}0.001 * * * \\
(0.000)\end{array}$ & $\begin{array}{r}0.001 * * \\
(0.000)\end{array}$ & $\begin{array}{r}0.001 * * \\
(0.000)\end{array}$ \\
\hline Logistic performance index & $\begin{array}{r}1.063 * * \\
(0.438)\end{array}$ & $\begin{array}{r}1.100 * * \\
(0.442)\end{array}$ & $\begin{array}{r}1.174 * * \\
(0.460)\end{array}$ & $\begin{array}{r}1.325 * * \\
(0.519)\end{array}$ & $\begin{array}{r}1.325 * * \\
(0.519)\end{array}$ \\
\hline Primary educations $\%$ & $\begin{array}{r}-0.002 \\
(0.009)\end{array}$ & & & $\begin{array}{r}0.003 \\
(0.007)\end{array}$ & $\begin{array}{r}0.003 \\
(0.007)\end{array}$ \\
\hline Secondary education $\%$ & & $\begin{array}{r}-0.006 \\
(0.008)\end{array}$ & & $\begin{array}{r}0.001 \\
(0.011)\end{array}$ & $\begin{array}{r}0.001 \\
(0.011)\end{array}$ \\
\hline Tertiary education $\%$ & & & $\begin{array}{r}-0.009 \\
(0.016)\end{array}$ & $\begin{array}{r}-0.015 \\
(0.017)\end{array}$ & $\begin{array}{r}-0.015 \\
(0.017)\end{array}$ \\
\hline Distance-log & & & & & $\begin{array}{r}-1.874 * * * \\
(0.518)\end{array}$ \\
\hline Product of partners' GDP-log & $\begin{array}{r}0.605^{* *} \\
(0.240)\end{array}$ & $\begin{array}{r}0.601 * * * \\
(0.207)\end{array}$ & $\begin{array}{r}0.645 * * * \\
(0.237)\end{array}$ & $\begin{array}{r}0.635 * * \\
(0.253)\end{array}$ & $\begin{array}{r}0.635 * * \\
(0.253)\end{array}$ \\
\hline Border & & & & & $\begin{array}{r}-1.232 \\
(1.039) \\
\end{array}$ \\
\hline Number of observations & 29,934 & 29,934 & 29,934 & 29,934 & 32,703 \\
\hline Partner fixed effect & Yes & Yes & Yes & Yes & Yes \\
\hline Year effect & Yes & Yes & Yes & Yes & Yes \\
\hline Wald chi-squared & 30 & 29 & 29 & 34 & 117,062 \\
\hline
\end{tabular}

Notes: $* * *, * *$, and $*$ indicate $1 \%, 5 \%$, and $10 \%$ level of statistical significance, respectively. Robust standard errors clustered by partner are in parentheses. FE and RE refer to that the estimations are conducted under PPML with fixed effect and random effect respectively.

To check the robustness of the estimation, again I estimate the model with some adjustment of the variables as shown in Result Table 2. The results for the main variables of the interest remain consistent. One additional finding is that improving the quality of the governance is a way to improve the exports but the liberalization process and improving the quality of governance process should proceed side by side (Table 7 last column). Just making openness dose not provide expected results to boost the exports. Also, trading with the large economies helps to improve the trade performance. 
Result Table 7. Gravity model PPML estimation results 2005-2018

\begin{tabular}{|c|c|c|c|c|}
\hline Dependent variable exports US\$ & (PPML-FE) & (PPML-RE) & (PPML-RE) & (PPML-RE) \\
\hline High-value to weight products-log & $\begin{array}{r}0.198 * * * \\
(0.054)\end{array}$ & $\begin{array}{r}0.198 * * * \\
(0.054)\end{array}$ & $\begin{array}{r}0.198 * * * \\
(0.054)\end{array}$ & $\begin{array}{r}0.196^{* * * *} \\
(0.055)\end{array}$ \\
\hline Liberalization & $\begin{array}{c}0.001 * \\
(0.000)\end{array}$ & $\begin{array}{c}0.001^{*} \\
(0.000)\end{array}$ & $\begin{array}{r}0.001 * * \\
(0.000)\end{array}$ & $\begin{array}{r}-0.453^{*} \\
(0.243)\end{array}$ \\
\hline Governance & $\begin{array}{r}-0.672 * * \\
(0.291)\end{array}$ & $\begin{array}{r}-0.672 * * \\
(0.291)\end{array}$ & $\begin{array}{r}-1.003 * * \\
(0.407)\end{array}$ & $\begin{array}{l}6.518^{*} \\
(3.805)\end{array}$ \\
\hline Liberalization*Governance & & & & $\begin{array}{r}-0.613 * \\
(0.328)\end{array}$ \\
\hline Logistic performance index & $\begin{array}{r}1.541 * * * \\
(0.552)\end{array}$ & $\begin{array}{r}1.541 * * * \\
(0.552)\end{array}$ & $\begin{array}{r}1.621 * * * \\
(0.536)\end{array}$ & $\begin{array}{l}1.216^{*} \\
(0.627)\end{array}$ \\
\hline Primary educations $\%$ & $\begin{array}{r}-0.001 \\
(0.009)\end{array}$ & $\begin{array}{r}-0.001 \\
(0.009)\end{array}$ & $\begin{array}{r}-0.003 \\
(0.005)\end{array}$ & $\begin{array}{r}-0.005 \\
(0.004)\end{array}$ \\
\hline Secondary education $\%$ & & & $\begin{array}{r}-0.016 \\
(0.014)\end{array}$ & $\begin{array}{r}-0.030 \\
(0.020)\end{array}$ \\
\hline Tertiary education $\%$ & & & $\begin{array}{r}0.010 \\
(0.021)\end{array}$ & $\begin{array}{r}0.022 \\
(0.026)\end{array}$ \\
\hline Distance-log & & $\begin{array}{r}-1.835 * * * \\
(0.497)\end{array}$ & $\begin{array}{r}-1.847 * * * \\
(0.524)\end{array}$ & $\begin{array}{r}-1.731 * * * \\
(0.567)\end{array}$ \\
\hline Product of partners' GDP-log & $\begin{array}{r}0.615 * * \\
(0.241)\end{array}$ & $\begin{array}{r}0.615 * * \\
(0.241)\end{array}$ & $\begin{array}{r}0.622 * * \\
(0.255)\end{array}$ & $\begin{array}{r}0.566 * * \\
(0.273)\end{array}$ \\
\hline Border & & $\begin{array}{r}-1.154 \\
(0.997) \\
\end{array}$ & $\begin{array}{r}-1.181 \\
(1.055) \\
\end{array}$ & $\begin{array}{r}-0.949 \\
(1.146) \\
\end{array}$ \\
\hline Number of observations & 29,934 & 32,703 & 32,703 & 32,703 \\
\hline Partner fixed effect & Yes & Yes & Yes & Yes \\
\hline Year effect & Yes & Yes & Yes & Yes \\
\hline Wald chi-squared & 30 & 99,743 & 102,397 & 105,087 \\
\hline
\end{tabular}

Notes: $* * *, * *$, and $*$ indicate $1 \%, 5 \%$, and $10 \%$ level of statistical significance, respectively. Robust standard errors clustered by partner are in parentheses. FE and RE refer to that the estimations are conducted under PPML with fixed effect and random effect respectively.

\section{Conclusion and Policy Inferences}

Nepal's export performance is not as expected by its stakeholders. Thus, based on the descriptive and econometric analysis from this study, in sum, we suggest some strategies to boost Nepal's trade in the days to come as listed in the below.

\subsection{Focusing on High-value to Weight Products}

Nepal needs to focus on high-value to weight products. Doing this will not only support to minimise transportation costs, but also it will help to catch up with global trend on which air cargo is increasing faster than the ocean-based vessel cargo to suit the landlocked countries' cases. Unfortunately, following the trend of other poor countries, Nepal also exports low-value to weight products compared to those exported by developed countries as stated in Finger and Yeats (1976). If this contradictory situation is analysed, we see the need of strategic attention on high-value to weight products in landlocked countries so that it will be possible air transport-based exports as suggested in Arvis (2007). Also, an important fact is that the international air shipping costs have been declined sharply that can reduce the gap of transportation costs between landlocked and coastal countries (Hummels, 2007).

Considering the geographical consideration of the country, Nepal would be in better position tying of its trade with the vibrant service sector. However, boosting the manufacturing sector is more effective way to create much needed employment for the low and semi-skilled manpower.

\subsection{Manufacturing-focused Infrastructure}

Nepal needs to build manufacturing-focussed infrastructure to improve the logistic performance index and trade 
competitiveness. Due to geographical constraints, Nepal naturally has additional costs. To compensate these costs, Nepal needs to build a heavy infrastructure and solve to connectivity issues with the priority in making manufacturing hubs and global connectivity with a solid airline hub to enhance the capacity to participate in global production network.

Nepal has just signed in one belt one road (OBOR) project initiated by our northern neighbour, China. Nepal should be able to take benefits with trade focused strategies taking the opportunities from OBOR as part of domestic and international trade linkage. Manufacturing hubs to be developed, even with tax rebate provision for some years, in the form of specific economic and industrial zone etc. connecting agriculture, tourism and industry with integrated approach. Investment needs to be mobilised heavily for manufacturing focused infrastructure and connectivity so that the state of trade facilitation would be improved.

\subsection{Bilateral Trade Agreements}

Surprisingly, Nepal does not have any specific effective trade agreements with the top 15 trade partners. The role of bilateral and multilateral trade agreements are well established facts in this era of globalization, which flourishes only at the condition of free movement of capital, goods and services. These types of movements are possible only with the application of trade agreements that allows free or comfortable access to more advanced markets for Nepalese products.

\subsection{Tie up the Education with Production}

As found in the empirical estimation, Nepal's none of the education variables are supporting the exports. Education system needs to be developed to increase the output of the nation that will help to increase the exports. This could be possible by adopting more vocational types of education that provides production skills to the labour force and increase the productivity. The education should make labour force semi-skilled or skilled so that more economic activities are possible. Hence, tying the education system with the manufacturing would make a better strategy to boost Nepal's international trade focusing outflows of Nepalese products.

\subsection{Improve the Quality of the Governance to Suit the Reform Process}

The quality of the governance builds the confidence in the investors creating a favourable environment for the proper enforcement of the contract, a crucial aspect for the business dealings. Nepal's poor score in the governance indicator, mainly caused by the political instability, is a niggling cause for the unfavourable business environment. Thus, one of the major strategies should be adopted to improve the quality of the governance side by side enhancing the liberalisation process.

\subsection{Second Generation Policy Reform}

Nepal is the earlier entrant in the reform policy in the region. But there are some reversal during last decades and Nepal is unable to take the benefits from reform process due to the lack of business environment caused by the poor scores on governance. The first-generation reforms are not enough to catch up the much-needed policy reform at this stage. Therefore, Nepal should adopt the strategy to make second generation systematic policy reform to boost the investment, thus, to boost the exports. Therefore, Nepal should focus more on institution buildings so that a meaningful investment climate is build up.

\section{Make trade friendly exchange rate system}

Nepal's currency is tied up (pegged) with Indian currency-Indian Rupee (IR) and it has not been adjusted since 1993 (see Ramesh C. Paudel and Burke (2015) for details). The fixed rate without adjustment for more than two decades has resulted an exchange rate appreciation, which has adversely affected Nepal's exports, especially to third-country markets. This scenario should be dealt carefully while preparing the trade strategies.

\section{References}

Acharya, M., Khatiwada, Y. R., \& Aryal, S. (2003). Structural Adjustment Policies and Poverty Eradication: Institute for Integrated Development Studies, Kathmandu, Nepal.

Arvis, J.-F., Gael Raballand, \& Jean -Francois Marteau. (2007). The Cost of Being Landlocked: Logistics Costs and Supply Chain Reliability, 4258. Policy Research Working Paper.

Behar, A., \& Venables, A. J. (2010). Transport Costs and International Trade: Edward Elgar.

Bergeijk, P. A. G. V., \& Brakman, S. (Eds.) (2010). The gravity model in international trade: Advances and applications.Cambridge: Cambridge University Press.

Borchert, I., Gootiiz, B., Grover, A., \& Mattoo, A. (2012). Landlocked or policy locked? how services trade protection deepens economic isolation. Policy Research Working Paper, 5942, World Bank.

CEPII. (2019). The CEPII Gravity Dataset http://www.cepii.fr/anglaisgraph/bdd/gravity.asp (Accessed on 16/04/2019). 
Chambers, M., \& Liu, M. (2012). Maritime Trade and Transportation by the Numbers. Retrieved from

De Sousa, J. (2012). The Currency Union Effect on Trade is Decreasing over Time. Economics Letters, 117(3), 917-920.

Faye, M. L., Mcarthur, J. W., Sachs, J. D., \& Snow, T. (2004). The Challenges Facing Landlocked Developing Countries. Journal of Human Development, 5, 31-68.

Finger, J. M., \& Yeats, A. J. (1976). Effective Protection by Transportation Costs and Tariffs: A Comparison of Magnitudes. The Quarterly Journal of Economics, 90(1), 169-176.

Grigoriou, C. (2007). Landlockedness, Infrastructure and Trade: New Estimates for Central Asian Countries. Policy Research Working Paper, 4335, World Bank.

Helleiner, G. K. (1973). Manufactured Exports from Less-Developed Countries and Multinational Firms. The Economic Journal, 83(329), 21-47. https://doi.org/10.2307/2231098

Hummels, D. (1999). Have International Transportation Costs Declined? Working Paper. University of Chicago.

Hummels, D. (2007). Transportation Costs and International Trade in the Second Era of Globalization. Journal of Economic Perspectives, 21(3), 131-154. https://doi.org/10.1257/jep.21.3.131

Kaufmann, D., Kraay, A., \& Mastruzzi, M. (2011). The worldwide governance indicators: methodology and analytical issues. Hague Journal on the Rule of Law, 3(2), 220-246.

Limão, N., \& Venables, A. J. (2001). Infrastructure, Geographical Disadvantage, Transport Costs, and Trade. The World Bank Economic Review, 15(3), 451-479. https://doi.org/10.1093/wber/15.3.451

Ng, F., \& Yeats, A. (2003). Export Profiles of Small Landlocked Countries: A Case Study Focusing on their Implications for Lesotho Vol. 3085. Policy Research Working Paper Retrieved from http://search.proquest.com/docview/56215233? accountid=8330

Paudel, R. C. (2014). Export Performance in Developing Countries: A Comparative Perspective. Working Papers in Trade and Development, 2014/2, Australian National University, Australia.

Paudel, R. C., \& Burke, P. J. (2015). Exchange Rate Policy and Export Performance in a Landlocked Developing Country: The Case of Nepal. Journal of Asian Economics, 38, 55-63. https://doi.org/10.1016/j.asieco.2015.04.003

Paudel, R. C., \& Wagle, S. (2017). Nepal's Trade Performance and Potential with Regional Partners. In J. Menon \& T. N. Srinivasan (Eds.), Integrating South and East Asia: Economics of Regional Cooperation and Development, 114-136. Delhi: Oxford University Press.

Pursell, G. (2011). Routledge Handbook of South Asian Economies: Routledge, London, UK.

Rajkarnikar, P. R. (2010). Adequacy and Effectiveness of Logistic Services in Nepal: Implication for Export Performance. Asia-Pacific Research and Training Network on Trade Working Paper Series, 79.

Sharma, K. (2001). Liberalisation, Growth and Structural Change: Evidence from Nepalese Manufacturing'. Applied Economics, 33, 1253-1261.

Silva, J. M. C. S., \& Tenreyro, S. (2006). The Log of Gravity. Review of Economics and Statistics, 88(4), $641-658$. https://doi.org/10.1162/rest.88.4.641

Tinbergen, J. (1962). Shaping the world economy: Suggestions for an international economic policy. New York: Twentieth Century Fund.

United States Department of Transportation. (2010). Freight Transportation: Global Highlights. Retrieved from Research and Innovative Technology Administration, Bureau of Transportation Statistics, The United States Department of Transportation, Washington, DC:

World Bank. (2019a). World Development Indicators. from World Bank, http://data.worldbank.org (accessed on 16/06/2019)

World Bank. (2019b). World Integrated Trade Solution, WITS database. from World Bank. http://wits.worldbank.org/WITS/WITS/Default-A.aspx?Page=Default (accessed on 16/04/2019)

World Bank. (2019c). Worldwide Governance Indicators. from World Bank. http://databank.worldbank.org/data/reports.aspx?source=Worldwide-Governance-Indicators\#(accessed on 1/04/2019) 


\section{Appendix 1}

Variable description and data sources

\begin{tabular}{lll}
\hline Variables & Details and expected sign & Data source \\
\hline X & $\begin{array}{l}\text { Nepal's product level annual exports to its trading partners, the } \\
\text { dependent variable, measured in US\$ current price }\end{array}$ & World Bank (2019b) \\
LIB & Openness measured by weighted average tariff rate for all products (-) & World Bank (2019a) \\
EDU & Gross enrolment in Secondary and tertiary education (+) & World Bank (2019a) \\
VALWT & Value to weight ratio of the exported products (+) & World Bank (2019b) \\
GDP & Product of the exporter's and importers' gross domestic products in & World Bank (2019a) \\
& US\$, current price (+) & \\
DIS & Distance between exporter's and importers' most populated cities (-) & CEPII (2016). \\
LAN & Common language, cultural affinity (+) & CEPII (2016). \\
BOR & Common border of trading countries (+) & CEPII (2016). \\
BTA & Bilateral trade agreements, binarv dummv (+) & De Sousa (2012) \\
\hline
\end{tabular}

\section{Copyrights}

Copyright for this article is retained by the author(s), with first publication rights granted to the journal.

This is an open-access article distributed under the terms and conditions of the Creative Commons Attribution license which permits unrestricted use, distribution, and reproduction in any medium, provided the original work is properly cited. 